\title{
Potential inhibitory effects of the traditional herbal prescription Hyangso-san against skin inflammation via inhibition of chemokine production and inactivation of STAT1 in HaCaT keratinocytes
}

\author{
HYE-SUN LIM ${ }^{1}$, SAE-ROM YOO ${ }^{2}$, MEE-YOUNG LEE ${ }^{2}$, CHANG-SEOB SEO ${ }^{2}$, \\ HYEUN-KYOO SHIN ${ }^{2}$ and SOO-JIN JEONG ${ }^{1,3}$ \\ ${ }^{1}$ Herbal Medicine Research Division; ${ }^{2}$ K-herb Research Center, Korea Institute of Oriental Medicine, Yuseong, Daejeon 34054; \\ ${ }^{3}$ Korean Medicine Life Science, University of Science and Technology, Yuseong, Daejeon 34113, Republic of Korea
}

Received June 15, 2016; Accepted April 20, 2017

DOI: $10.3892 / \mathrm{mmr} .2017 .8172$

\begin{abstract}
Inflammatory skin disease are caused by multiple factors, including susceptibility genes, and immunologic and environmental factors, and are characterized by an increase in epidermal thickness and the infiltration of macrophages, keratinocytes, mast cells, eosinophils and other inflammatory cells. Keratinocytes may serve an important role in the pathogenesis of inflammatory skin diseases. The traditional herbal decoction Hyangso-san (HSS) has been used to treat symptoms of the common cold, including headache, pantalgia, fever and chills. However, to the best of our knowledge, there is no evidence regarding whether HSS has an effect on inflammatory skin diseases. The present study investigated the anti-skin inflammation activity of HSS using the HaCaT human keratinocyte cell line. The mRNA expression and production of inflammatory chemokines, including $\mathrm{C}-\mathrm{C}$ motif chemokine ligand 22 (CCL22), CCL5, CCL17, and interleukin (IL)-8, was measured using reverse transcription polymerase chain reaction and ELISA analyses. Moreover, we evaluated the effect of HSS on signal transducer and activator of transcription 1 (STAT1) pathway in HaCaT cells. The cells were stimulated with tumor necrosis factor- $\alpha$ (TNF- $\alpha)$ and interferon- $\gamma($ IFN- $\gamma$ ) to induce an inflammatory reaction. In the TNF- $\alpha$ - and IFN- $\gamma$-stimulated cells, the production and expression of inflammatory chemokines were observed, including CCL22, CCL5, CCL17 and IL-8. In addition, stimulation with TNF- $\alpha$ and IFN- $\gamma$ increased the phosphorylation and nuclear translocation of STAT1 in HaCaT cells. By contrast, HSS extract
\end{abstract}

Correspondence to: Dr Soo-Jin Jeong, Herbal Medicine Research Division, Korea Institute of Oriental Medicine, 1672 Yuseong-daero, Yuseong, Daejeon 34054, Republic of Korea

E-mail: sjijeong@kiom.re.kr

Key words: Hyangso-san, chemokine, signal transducer and activator of transcription 1, inflammatory skin disease, keratinocyte treatment inhibited TNF- $\alpha$ - and IFN- $\gamma$-induced STAT1 activation. Results from the present study indicated that HSS exhibited inhibitory effects on TNF- $\alpha$ - and IFN- $\gamma$-mediated chemokine production and expression by targeting STAT1 in keratinocytes. Overall, the results indicated that HSS may be a potential candidate therapeutic drug for inflammatory skin diseases such as atopic dermatitis.

\section{Introduction}

Skin inflammation is the most common complaint in dermatologic diseases. Inflammatory skin diseases are divided into acute and chronic conditions (1). Acute skin inflammation is associated with occasional rashes, itching and skin redness, and may be caused by ultraviolet or ionizing radiation, allergens or chemical irritants. Chronic inflammatory skin diseases include atopic dermatitis (such as eczema), seborrheic dermatitis, psoriasis and rosacea. Chronic inflammatory skin diseases may lead to significant and serious disruption of skin immunity (2). The prevalence of atopic dermatitis in particular is gradually increasing and affected 230 million people worldwide in 2010 (3).

The type $2 \mathrm{~T}$ helper (Th2) cell-mediated inflammatory response is a crucial event in the development of inflammatory skin diseases $(4,5)$. Th2 cells are attracted to the skin by inflammatory chemokines, including $\mathrm{C}-\mathrm{C}$ motif chemokine ligand 5 (CCL5), CCL17, CCL22 and interleukin-8 (IL-8; also known as CXCL8) (6-9), that are synthesized by epidermal keratinocytes (10). Therefore, the inflammatory chemokines are considered important therapeutic targets for the treatment of inflammatory skin diseases. In addition, signal transducer and activator of transcription 1 (STAT1) has been reported to have pivotal roles in the regulation of chemokine production and inflammation (11). STAT1 is transactivated when keratinocytes are exposed to tumor necrosis factor- $\alpha$ (TNF- $\alpha)$ and/or interferon- $\gamma$ (IFN- $\gamma$ ) (12).

Corticosteroids are the most commonly used medication to treat inflammatory skin diseases, as they are effective at controlling mild to moderate dermatitis with short-term 
use. However, long term administration of topical steroids may cause severe side effects, including skin atrophy, striae and telangiectasia (13). Thus, it is necessary to develop anti-inflammatory drugs with improved efficacy against skin inflammation, with fewer side effects, that may be used over longer periods of time. Recently, various studies have reported on the inhibitory effects of traditional herbal formulas on skin inflammation (14-18) and have indicated that herbal formulas may be valuable alternative medicines for treating skin inflammation diseases.

Hyangso-san (HSS) is a traditional herbal formula that has been used in Korea to treat symptoms of the common cold, including headache, pantalgia, fever and chills (19). HSS comprises seven herbal medicines, including Cyperi Rhizoma, PerillaeHerba,Atractylodis Rhizoma,CitriUnshiiPericarpium, Glycyrrhizae Radix et Rhizoma, Zingiberis Rhizoma Crudus and Allii Radix. Previous studies have indicated antidepressant and anti-stress effects of HSS $(20,21)$; however, to the best of our knowledge, the anti-inflammatory effects of HSS have not been examined. Therefore, the present study investigated the anti-inflammatory effects of HSS in skin using a TNF- $\alpha$ - and IFN- $\gamma$-stimulated HaCaT human keratinocyte cell line.

\section{Materials and methods}

Plant materials. HSS is comprised of seven herbal medicines, and each of the raw materials was purchased from Kwangmyungdang Medicinal Herbs (Ulsan, Korea) (Table I). All crude materials were analyzed by pharmacognosists Professor Je-Hyun Lee and Professor Young-Bae Seo (both from College of Oriental Medicine, Daejeon University, Daejeon, Korea). Voucher specimens (2012-KE44-1-7) have been deposited at the K-herb Research Center, Korean Institute of Oriental Medicine (Daejeon, Korea).

Chemicals and reagents. Liquiritin and glycyrrhizin were purchased from Wako Pure Chemical Industries, Ltd. (Osaka, Japan). Liquiritin apioside and hesperidin were purchased from Shanghai Sunny Biotech Co., Ltd. (Shanghai, China). Rosmarinic acid and atractylenolide III were purchased from Sigma-Aldrich (Merck KGaA, Darmstadt, Germany) and SK Biotek Co., Ltd. (Daejeon, Korea), respectively. Purities of the six reference standards, including liquiritin apioside, liquiritin, hesperidin, rosmarinic acid, glycyrrhizin and atractylenolide III, were $>98.0 \%$ as determined by high-performance liquid chromatography (HPLC) analysis, as described below. HPLC-grade methanol, acetonitrile and water were purchased from Avantor (Center Valley, PA, USA). Reagent-grade formic acid was purchased from Sigma-Aldrich (Merck KGaA).

Preparation of HSS water extract. To prepare the HSS water decoction, the crude materials Cyperi Rhizoma (1,111 g), Perillae Herba (1,111 g), Atractylodis Rhizoma (833 g), Citri Unshii Pericarpium (556 g), Glycyrrhizae Radix et Rhizoma (278 g), Zingiberis Rhizoma Crudus (556 g) and Allii Radix (556 g) were mixed and extracted with 501 of distilled water at $100^{\circ} \mathrm{C}$ for $2 \mathrm{~h}$ under pressure $(98 \mathrm{kPa})$ using a COSMOS-660 Electric Vacuum Extractor (Kyungseo Machine Co., Incheon, Korea). The extracted solution was filtered using a standard sieve (no. 270, $53 \mu \mathrm{m}$; Chung Gye Sang Gong Sa,
Seoul, Korea), and the filtered solution was subsequently freeze-dried to produce a powder using a PVTFD10RS vacuum freeze dryer. The amount of freeze-dried HSS powder obtained was $670.6 \mathrm{~g}$ (yield, 13.4\%).

Cell culture. HaCaT human keratinocytes (CLS Cell Lines Service GmbH, Eppelheim, Germany) were incubated in Dulbecco's modified Eagle's medium supplemented with $10 \%$ heat-inactivated fetal bovine serum, penicillin $(100 \mathrm{U} / \mathrm{ml})$ and streptomycin $(100 \mu \mathrm{g} / \mathrm{ml})$ (all from Gibco; Thermo Fisher Scientific, Inc., Waltham, MA, USA) in an incubator containing $5 \% \mathrm{CO}_{2}$ at $37^{\circ} \mathrm{C}$.

Cytotoxicity test. A cytotoxicity assay was performed using Cell Counting Kit-8 (CCK-8; Dojindo Molecular Technologies, Inc., Kumamoto, Japan), according to the manufacturer's instructions. Briefly, HaCaT cells were seeded $\left(1 \times 10^{3}\right.$ cells/well) on a 96-well microplate and treated with various concentrations of $\operatorname{HSS}(125,250,500$ or $1,000 \mu \mathrm{g} / \mathrm{ml})$ for $24 \mathrm{~h}$ in an incubator containing $5 \% \mathrm{CO}_{2}$ at $37^{\circ} \mathrm{C}$. Control cells were treated with medium only. CCK-8 reagent $(10 \mu \mathrm{l})$ was added to each well and the mixture was incubated for $4 \mathrm{~h}$ in an incubator containing $5 \% \mathrm{CO}_{2}$ at $37^{\circ} \mathrm{C}$. The absorbance was read at $450 \mathrm{~nm}$ using a Benchmark Plus Microplate Reader (Bio-Rad Laboratories, Inc., Hercules, CA, USA). Cell viability was calculated using the following equation: Cell viability $(\%)=($ mean absorbance in $\mathrm{HSS}$ - treated cells/mean absorbance in untreated control cells) x 100.

Measurement of chemokine production by ELISA. The production of chemokines was measured using commercial kits for CCL22, CCL5, CCL17 and IL-8 (R\&D Systems, Inc., Minneapolis, MN, USA), according to the respective manufacturer's instructions. Briefly, HaCaT cells $\left(1 \times 10^{6}\right.$ cells/well) were cultured in 6-well plates for $18 \mathrm{~h}$ in an incubator containing 5\% $\mathrm{CO}_{2}$ at $37^{\circ} \mathrm{C}$. After reaching confluency, the cells were washed and treated with or without $\operatorname{HSS}(125,250$ or $500 \mu \mathrm{g} / \mathrm{ml})$ in $1 \mathrm{ml}$ of serum-free medium containing TNF- $\alpha$ and IFN- $\gamma$ (each $10 \mathrm{ng} / \mathrm{ml}$; R\&D Systems Inc.) for $24 \mathrm{~h}$. The culture supernatants were collected for $5 \mathrm{~min}$ at $16,000 \mathrm{x}$ g at $4^{\circ} \mathrm{C}$, and subjected to ELISA for each chemokine. Silymarin (6.25, 12.5 or $25 \mu \mathrm{g} / \mathrm{ml}$; Sigma-Aldrich; Merck KGaA) was used as a positive control.

Reverse transcription-polymerase chain reaction (RT-PCR). RT-PCR analyses for chemokine expression were performed as previously described (17). Briefly, HaCaT cells $\left(1 \times 10^{6}\right.$ cells/well) were cultured to $80-90 \%$ confluence in 6 -well plates. When the cells reached confluence, they were washed and treated with HSS in $1 \mathrm{ml}$ serum-free medium (Gibco; Thermo Fisher Scientific, Inc.) supplemented with TNF- $\alpha$ - and IFN- $\gamma$ for $24 \mathrm{~h}$. Total RNA (1 $\mu \mathrm{g})$ was isolated using the TRIzol reagent (Invitrogen; Thermo Fisher Scientific, Inc.). cDNA was synthesized using the iScript cDNA Synthesis kit and the PCR reaction (iScript ${ }^{\mathrm{TM}}$ Reverse Transcription Supermix)(both from Bio-Rad Laboratories, Inc.) was performed using the following gene-specific primers: CCL22 forward, 5'-AGGACAGAGCATGGCTCG CCTACAGA-3' and reverse, 5'-TAATGGCAGGGAGCT AGGGCTCCTGA-3'; CCL5 forward, 5'-CCCCGTGCCGAG 
Table I. Herbal composition of Hyangso-san water extract.

\begin{tabular}{|c|c|c|c|c|}
\hline Herbal medicine & Scientific name & Family & Ratio (\%) & Origin \\
\hline Cyperi Rhizoma & Cyperus rotundus Linnaeus & Cyperaceae & 22.2 & Yeongcheon, Korea \\
\hline Perillae Herba & Perilla frutescens Britton var. acuta Kudo & Lamiaceae & 22.2 & Namwon, Korea \\
\hline Atractylodis Rhizoma & Atractylodes chinensis Koidzumi & Asteraceae & 16.7 & China \\
\hline Citri Unshii Pericarpium & Citrus unshiu Markovich & Rutaceae & 11.1 & Jeju, Korea \\
\hline Glycyrrhizae Radix et Rhizoma & Glycyrrhiza uralensis Fischer & Fabaceae & 5.6 & China \\
\hline Zingiberis Rhizoma Crudus & Zingiber officinale Roscoe & Zingiberaceae & 11.1 & Ulsan, Korea \\
\hline Allii Radix & Allium fistulosum Linnaeus & Amaryllidaceae & 11.1 & Hanam, Korea \\
\hline
\end{tabular}

ATCAAGGAGTATTT-3' and reverse, 5'-CGTCCAGCC TGGGGAAGGTTTT TGTA-3'; CCL17 forward, 5'-ACT GCTCCAGGGATGCCATCGTTTTT-3' and reverse, 5'-ACA AGGGGATGGGATCTCCCTCACTG-3'; IL-8 forward, 5'-GTGGCTCTCTTGGCAGCCTTCCTGAT-3' and reverse, 5'-TCTCCACAACCCTCTGCACCCAGTTT-3'; and $\beta$-actin forward, 5'-GTGATGGCATGGACTGTGGT-3' and reverse, 5'-AAGGGTCATCATCTCTGCCC-3'. The PCR conditions were as follows: Twenty-five cycles of predenaturation at $94^{\circ} \mathrm{C}$ for $5 \mathrm{~min}$, denaturation at $94^{\circ} \mathrm{C}$ for $30 \mathrm{sec}$, annealing at $64^{\circ} \mathrm{C}$ for $1 \mathrm{~min}$, extension at $72^{\circ} \mathrm{C}$ for $90 \mathrm{sec}$ and final elongation at $72^{\circ} \mathrm{C}$ for $5 \mathrm{~min}$.

Western blot analysis. HaCaT cells $\left(1 \times 10^{6}\right.$ cells/well) were stimulated with TNF- $\alpha$ and IFN- $\gamma(10 \mathrm{ng} / \mathrm{ml}$ of each) with or without various concentrations of $\operatorname{HSS}(0,125,250$ or $500 \mu \mathrm{g} / \mathrm{ml}$ ) for $30 \mathrm{~min}$. Cells were lysed and protein fractions were extracted using the NE-PER Nuclear and Cytoplasmic Extraction reagents kit (Thermo Fisher Scientific, Inc.), according to the manufacturer's protocol. Protein concentrations were determined using a Bradford Protein Assay kit (Bio-Rad Laboratories, Inc.), according to the manufacturer's instructions. Equal amounts of nuclear extracts $(30 \mu \mathrm{g})$ were resolved by $10 \%$ SDS-PAGE and transferred to polyvinylidene fluoride membranes. The membranes were incubated with blocking buffer [5\% skim milk in TBS containing $20 \%$ Tween-20 (TBST)] for $1 \mathrm{~h}$ at room temperature, followed by overnight incubation at $4^{\circ} \mathrm{C}$ with primary antibodies against STAT1 (1:1,000, ab3987, mouse), phosphorylated (p)-STAT1 (1:1,000, ab109461, rabbit) (both from Abcam, Cambridge, UK), or $\beta$-actin $(1: 1,000,4967$, rabbit; Cell Signaling Technology, Inc., Danvers, MA, USA). The membranes were washed three times with TBST and incubated with a horseradish peroxidase-conjugated secondary antibody [1:3,000, cat. no. 111-035-003 (rabbit); cat. no. 115-035-003 (mouse); Jackson ImmunoResearch Laboratories, Inc., West Grove, PA, USA] for $1 \mathrm{~h}$ at room temperature. The membranes were washed three times with TBST and developed using an Enhanced Chemiluminescence kit (Thermo Fisher Scientific, Inc.). Images of developed membranes were captured using a Chemi-Doc Gel Imaging System (Bio-Rad Laboratories, Inc.).

Immunofluorescence assay. HaCaT cells ( $1 \times 10^{6}$ cells/well) were seeded onto glass coverslips and incubated with TNF- $\alpha$ and IFN- $\gamma$ (10 $\mathrm{ng} / \mathrm{ml}$ of each) in the presence or absence of HSS $(500 \mu \mathrm{g} / \mathrm{ml})$ for $30 \mathrm{~min}$ at $37^{\circ} \mathrm{C}$. The cells were fixed in
$4 \%$ paraformaldehyde and $100 \%$ acetone for $15 \mathrm{~min}$ at room temperature, and incubated in blocking solution $(0.5 \%$ bovine serum albumin; Thermo Fisher Scientific, Inc.) for $30 \mathrm{~min}$ at room temperature. The slides were probed with anti-STAT1 antibody (diluted 1:500, no. 9172; Cell Signaling Technology, Inc.) by overnight incubation at $4^{\circ} \mathrm{C}$, followed by incubation with Texas Red-conjugated anti-rabbit immunoglobulin $\mathrm{G}$ (diluted 1:500, A11037; Invitrogen; Thermo Fisher Scientific, Inc.) for $1 \mathrm{~h}$ at room temperature. The immunostained cells were mounted with medium containing DAPI (diluted 1:10,000, H-1200; Vector Laboratories, Inc., Burlingame, CA, USA) and visualized using an Olympus FluoView FV10i confocal microscope system (Olympus Corporation, Tokyo, Japan). Quantification of the effects was performed by measuring the density of $\mathrm{HaCaT}$ cells at x200 magnification using Image J 1.50i software (National Institutes of Health, Bethesda, MD, USA).

Chromatographic conditions. Quantitative analysis of the components in HSS was performed using a Shimadzu Prominence LC-20A series HPLC system (Shimadzu Corporation, Kyoto, Japan) equipped with a two LC-20AT pumps, a DGU-20A3 on-line degasser, a CTO-20A column oven, a SIL-20A auto sample injector and a SPD-M20A photodiode array (PDA) detector. Chromatographic data were recorded and processed using Lab Solution software version 5.54 SP3 (Shimadzu Corporation). Separation of the major components of HSS was achieved on a Phenomenex Gemini C18 column (250x4.6 mm, $5 \mu \mathrm{m}$; Phenomenex, Inc., Torrance, CA, USA) and the column oven temperature was maintained at $40^{\circ} \mathrm{C}$. The mobile phases consisted of $1.0 \%(\mathrm{v} / \mathrm{v})$ distilled water-acetonitrile, which both contained $0.1 \%(\mathrm{v} / \mathrm{v})$ formic acid. The gradient conditions for efficient separation of the major components was as follows: 5-60\% B (30 min), $60-100 \%$ B (10 min), held at $100 \%$ B (5 min), 100-5\% B (5 min) and held at $5 \% \mathrm{~B}$ for $10 \mathrm{~min}$. The flow rate and injection volume were $1 \mathrm{ml} / \mathrm{min}$ and $10 \mu \mathrm{l}$.

Statistical analysis. All experiments were repeated at least three times and data are presented as the mean \pm standard error of the mean. One-way analysis of variance was used to detect significant differences between the control and HSS-treatment groups using GraphPad Prism 7 (GraphPad Software, Inc., La Jolla, CA, USA) followed by Dunnett's post hoc multiple comparison test. $\mathrm{P}<0.05$ was considered to indicate a statistically significant difference. 


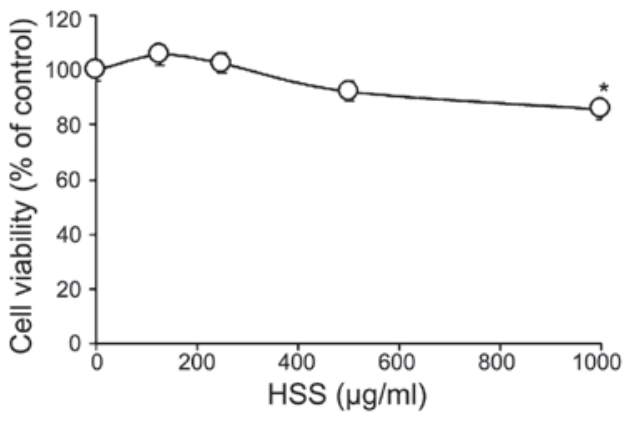

Figure 1. Cytotoxicity of the HSS extract in HaCaT cells. Cells were seeded into 96-well plates and treated with various concentrations of HSS water extract $(0,125,250,500$ or $1,000 \mu \mathrm{g} / \mathrm{ml})$ for $24 \mathrm{~h}$. Cell viability was assessed using a Cell Counting Kit- 8 assay. Data are presented as the mean \pm standard error of the mean of three independent experiments. "P<0.05 vs. non-treated cells. HSS, Hyangso-san.

A
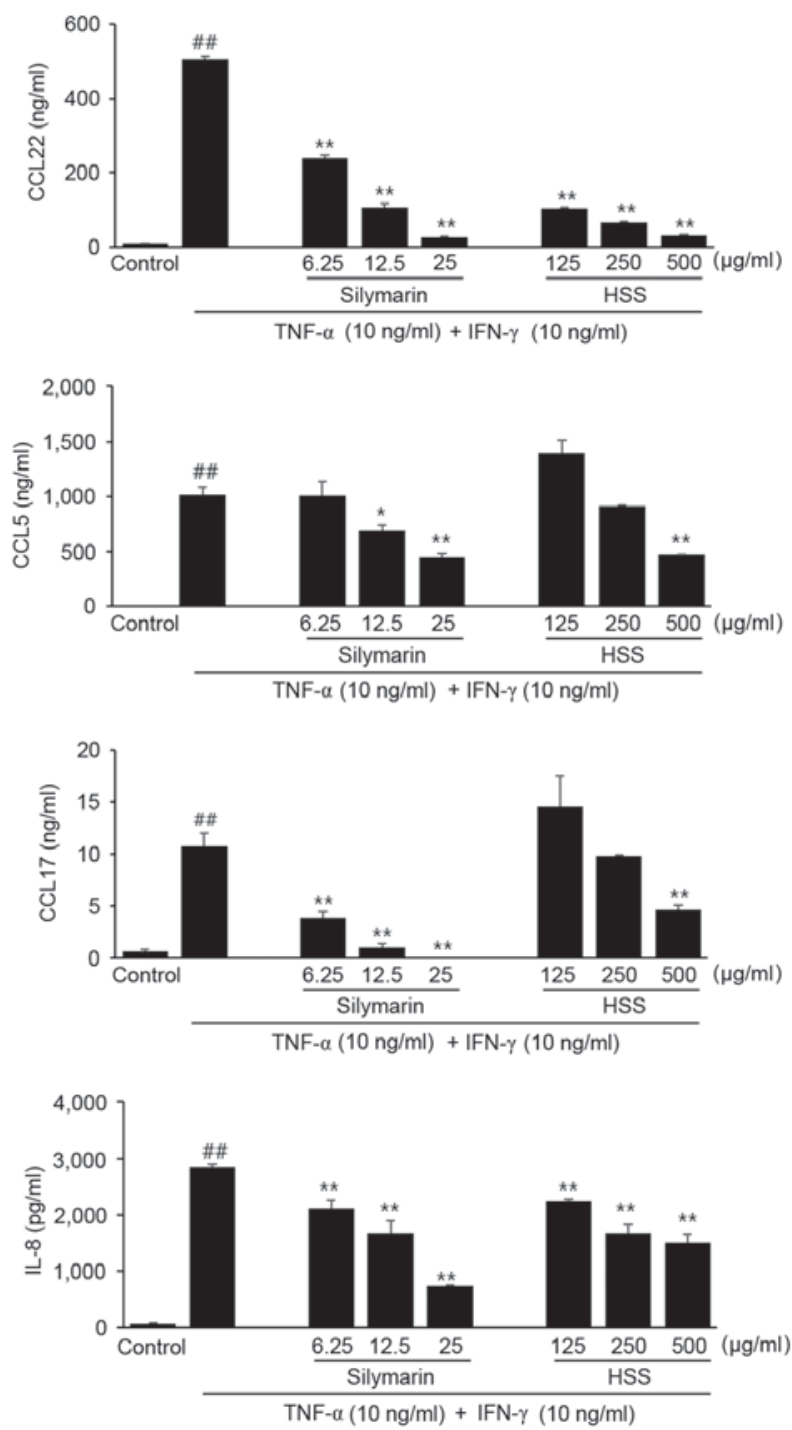

Figure 2. Effects of HSS on the production of chemokines in TNF- $\alpha$ - and IFN- $\gamma$-stimulated HaCaT cells. Production of (A) CCL22, (B) CCL5, (C) CCL17 and (D) IL- 8 was measured using the culture supernatant from cells co-treated with HSS extract $(125,250$ or $500 \mu \mathrm{g} / \mathrm{ml})$, and TNF- $\alpha$ and IFN- $\gamma(10 \mathrm{ng} / \mathrm{ml}$ each $)$ for $24 \mathrm{~h}$. Silymarin $(6.25,12.5$ or $25 \mu \mathrm{g} / \mathrm{ml})$ was used as a positive control. Data are presented as the mean \pm standard error of the mean of three independent experiments. ${ }^{\# \#} \mathrm{P}<0.01$ vs. control cells; ${ }^{*} \mathrm{P}<0.05$ and ${ }^{* *} \mathrm{P}<0.01$ vs. TNF- $\alpha$ - and IFN- $\gamma$-treated cells. CCL, C-C motif chemokine ligand; HSS, Hyangso-san; IFN, interferon; IL, interleukin; TNF, tumor necrosis factor.

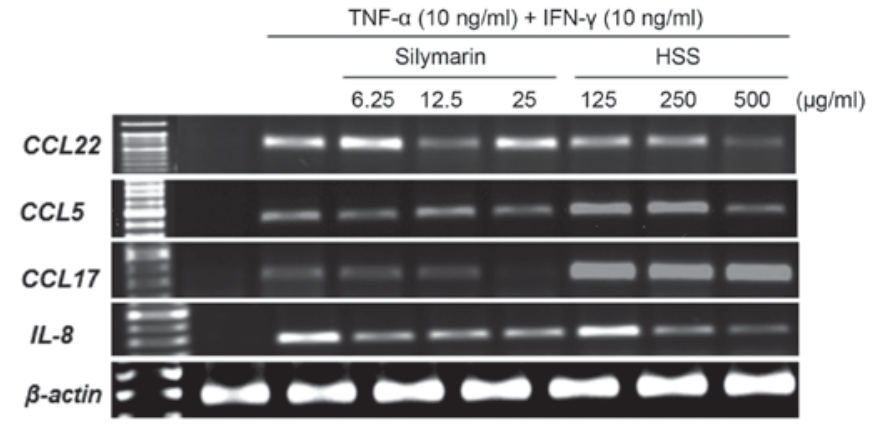

Figure 3.Effects of HSS on chemokine mRNA expression levels in TNF- $\alpha$ - and IFN- $\gamma$-stimulated $\mathrm{HaCaT}$ cells. Reverse transcription-polymerase chain reaction was performed to determine the mRNA levels of CCL22, CCL5, CCL17 and IL-8. $\beta$-actin was used as a housekeeping control gene. CCL, C-C motif chemokine ligand; HSS, Hyangso-san; IFN, interferon; IL, interleukin; TNF, tumor necrosis factor.

\section{Results}

Cytotoxic effects of HSS on HaCaT human keratinocyte cells. To determine the nontoxic concentrations of the HSS water extract in $\mathrm{HaCaT}$ cells, a cytotoxicity assay was performed. Cells were treated with various concentrations of HSS extract $(0,125,250,500$ or $1,000 \mu \mathrm{g} / \mathrm{ml})$ for $24 \mathrm{~h}$. As demonstrated in Fig. 1, cell viability was maintained at $>90 \%$ for up to $500 \mu \mathrm{g} / \mathrm{ml}(92.27 \pm 0.80 \%$ at $500 \mu \mathrm{g} / \mathrm{ml})$ but was reduced to $85.69 \pm 1.69 \%$ at $1,000 \mu \mathrm{g} / \mathrm{ml}$. These results indicated that HSS is nontoxic to the cells at physiologically relevant concentrations $(\leq 500 \mu \mathrm{g} / \mathrm{ml})$. Subsequent assays were performed in the range of nontoxic concentrations.

Inhibitory effects of HSS on chemokine protein production in TNF- $\alpha$ - and IFN- $\gamma$-stimulated HaCaT cells. To investigate whether HSS extract has inhibitory effects on inflammatory reactions in keratinocytes, ELISAs were performed to measure the production of inflammatory chemokines. Inflammatory reactions were induced by stimulating $\mathrm{HaCaT}$ cells with TNF- $\alpha$ and INF- $\gamma$, and concurrently treating the cells with or without various concentrations of HSS extract $(0,125,250$ or $500 \mu \mathrm{g} / \mathrm{ml}$ ) for $24 \mathrm{~h}$. Treatment with TNF- $\alpha$ and INF- $\gamma$ significantly increased the expression levels of CCL22, CCL5, CCL17 and IL-8 in HaCaT cells compared with untreated control cells (Fig. 2). However, HSS treatment significantly reduced the TNF- $\alpha$ - and INF- $\gamma$-mediated increase in CCL22 and IL-8 expression, in a dose-dependent manner (Fig. 2A and D). The inhibitory effects of HSS on CCL5 and CCL17 production were observed only at $500 \mu \mathrm{g} / \mathrm{ml}$, and not at the lower concentrations (Fig. 2B and C). A positive control, silymarin evoked a significant decrease in TNF- $\alpha$ - and IFN- $\gamma$-stimulated chemokine production. The inhibitory effects of HSS were similar to those of silymarin.

Inhibitory effects of HSS on chemokine mRNA expression in TNF- $\alpha$ - and IFN- $\gamma$-stimulated HaCaT cells. To confirm anti-inflammatory effects of HSS on HaCaT cells, RT-PCR was performed to assess the mRNA expression of the inflammatory chemokines CCL22, CCL17, CCL5 and IL-8. Consistent with the ELISA results aforementioned, HSS extract suppressed the mRNA expression levels of CCL22 
A
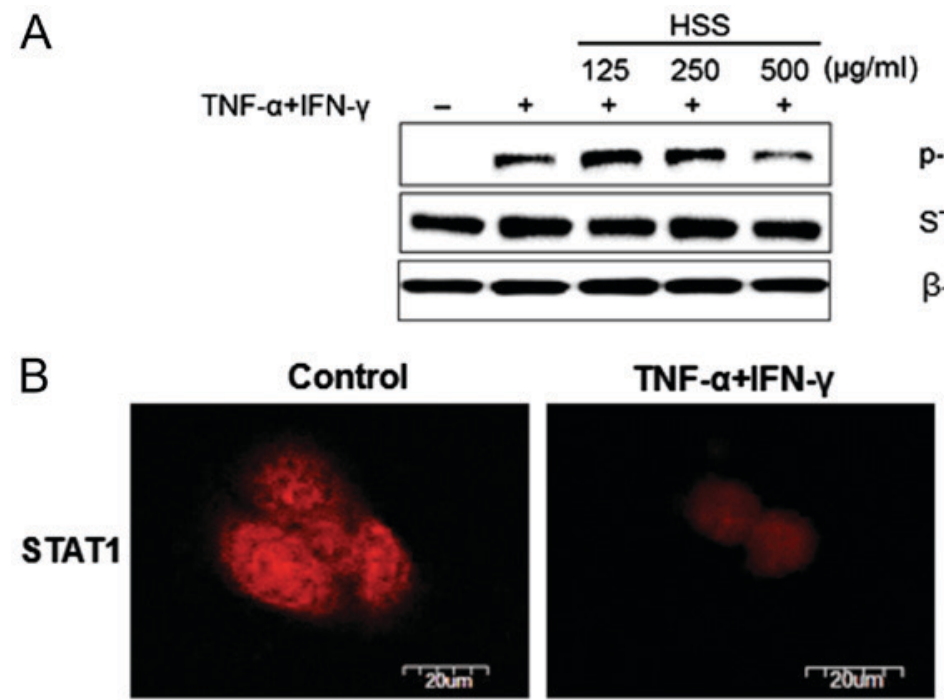

p-STAT1

STAT1

$\beta$-actin
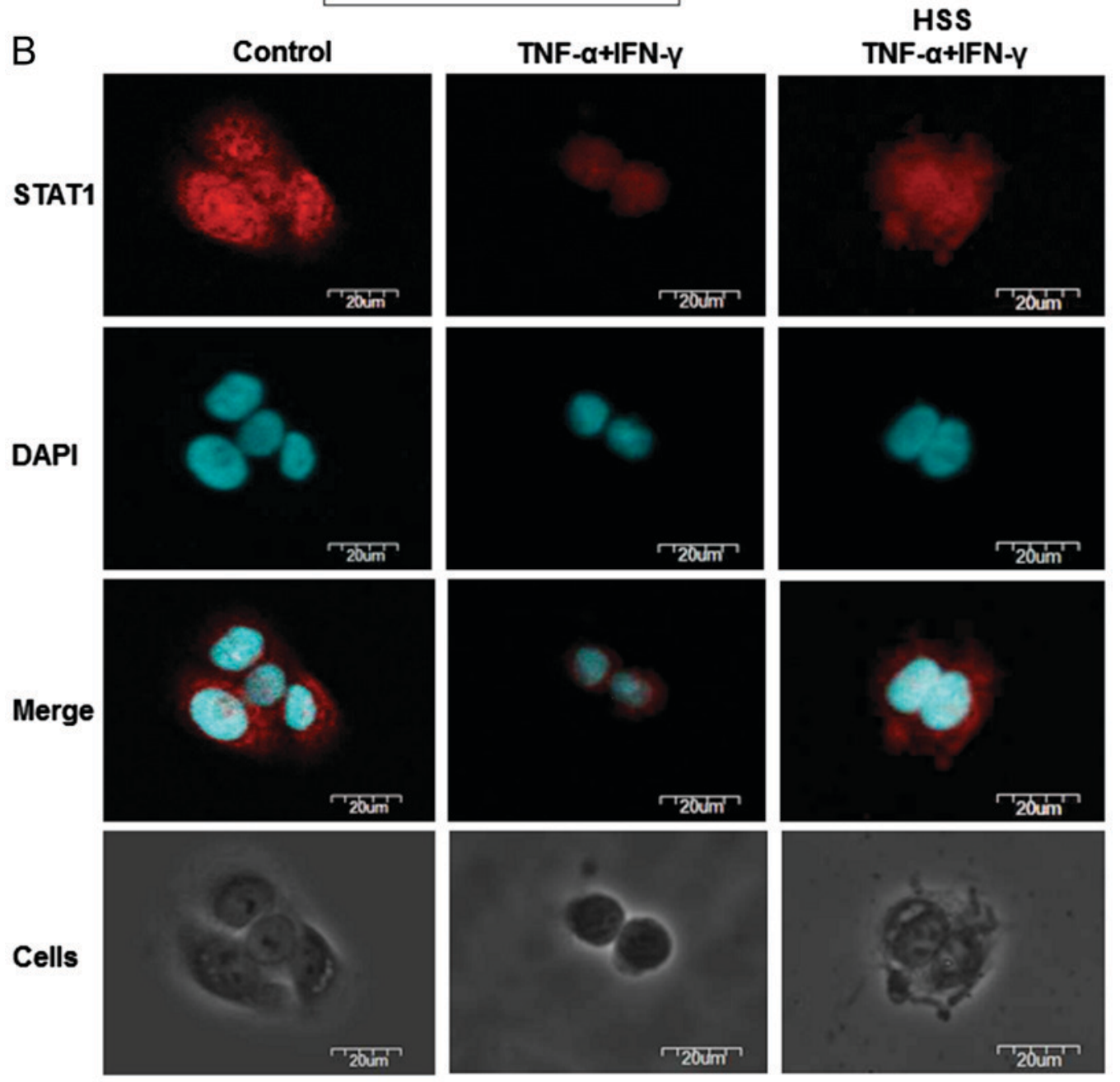

Figure 4. Effects of HSS on STAT1 activation in TNF- $\alpha$ - and IFN- $\gamma$-stimulated HaCaT cells. (A) Cells were treated with TNF- $\alpha$ and IFN- $\gamma(10 \mathrm{ng} / \mathrm{ml}$ each) in the absence or presence of HSS $(125,250$ or $500 \mu \mathrm{g} / \mathrm{ml})$ for $30 \mathrm{~min}$. Cell lysates were prepared and subjected to immunoblotting with anti-p-STAT1 and anti-STAT1 antibodies. (B) Cellular localization of STAT1 was analyzed by confocal microscopy. Cells were treated with TNF- $\alpha$ and IFN- $\gamma$ (10 ng/ml each) in the absence or presence of HSS $(500 \mu \mathrm{g} / \mathrm{ml})$ for $30 \mathrm{~min}$ on glass coverslips and incubated with anti-STAT1 primary antibody and Texas Red-conjugated secondary antibody. Immunostained cells were mounted with medium containing DAPI and visualized using an Olympus FluoView FV10i confocal microscope. HSS, Hyangso-san; IFN, interferon; p, phosphorylated; STAT1, signal transducer and activator of transcription 1; TNF, tumor necrosis factor.

and IL-8 in TNF- $\alpha$ - and IFN- $\gamma$-treated HaCaT cells. In addition, the inhibitory effect of CCL5 expression was observed at a concentration of $500 \mu \mathrm{g} / \mathrm{ml}$ in TNF- $\alpha$ - and IFN- $\gamma$-treated HaCaT cells (Fig. 3). However, the inhibitory effect on CCL17 expression by HSS was not affected. Silymarin was used as a positive control (22) for the production and expression of the chemokines, and it evoked a decrease in TNF- $\alpha$ - and IFN- $\gamma$-stimulated chemokine production (Fig. 3).

Effects of HSS on the activation of STAT1 in TNF- $\alpha$ - and IFN- $\gamma$-stimulated $\mathrm{HaCaT}$ cells. The transcription factor STAT1 serves an important role in the regulation of skin inflammation and is associated with chemokine production in keratinocytes that have been treated with inflammatory stimuli $(18,23)$. In the present study, TNF- $\alpha$ and IFN- $\gamma$ stimulation notably increased the expression levels of p-STAT1 compared with the untreated HaCaT control cells (Fig. 4A). Cells co-treated with HSS extract exhibited a reduction in the TNF- $\alpha$ - and IFN- $\gamma$-induced p-STAT1 expression at a dose of $500 \mu \mathrm{g} / \mathrm{ml}$, but not at lower concentrations (125 and $250 \mu \mathrm{g} / \mathrm{ml}$; Fig. 4A). To further confirm the involvement of STAT1 in the anti-inflammatory activity of HSS, immunocytochemical analysis was performed. HSS extract $(500 \mu \mathrm{g} / \mathrm{ml})$ co-treatment reversed the TNF- $\alpha$ - and IFN- $\gamma$-mediated decrease in the cytoplasmic expression of STAT1 in HaCaT cells (Fig. 4B). 


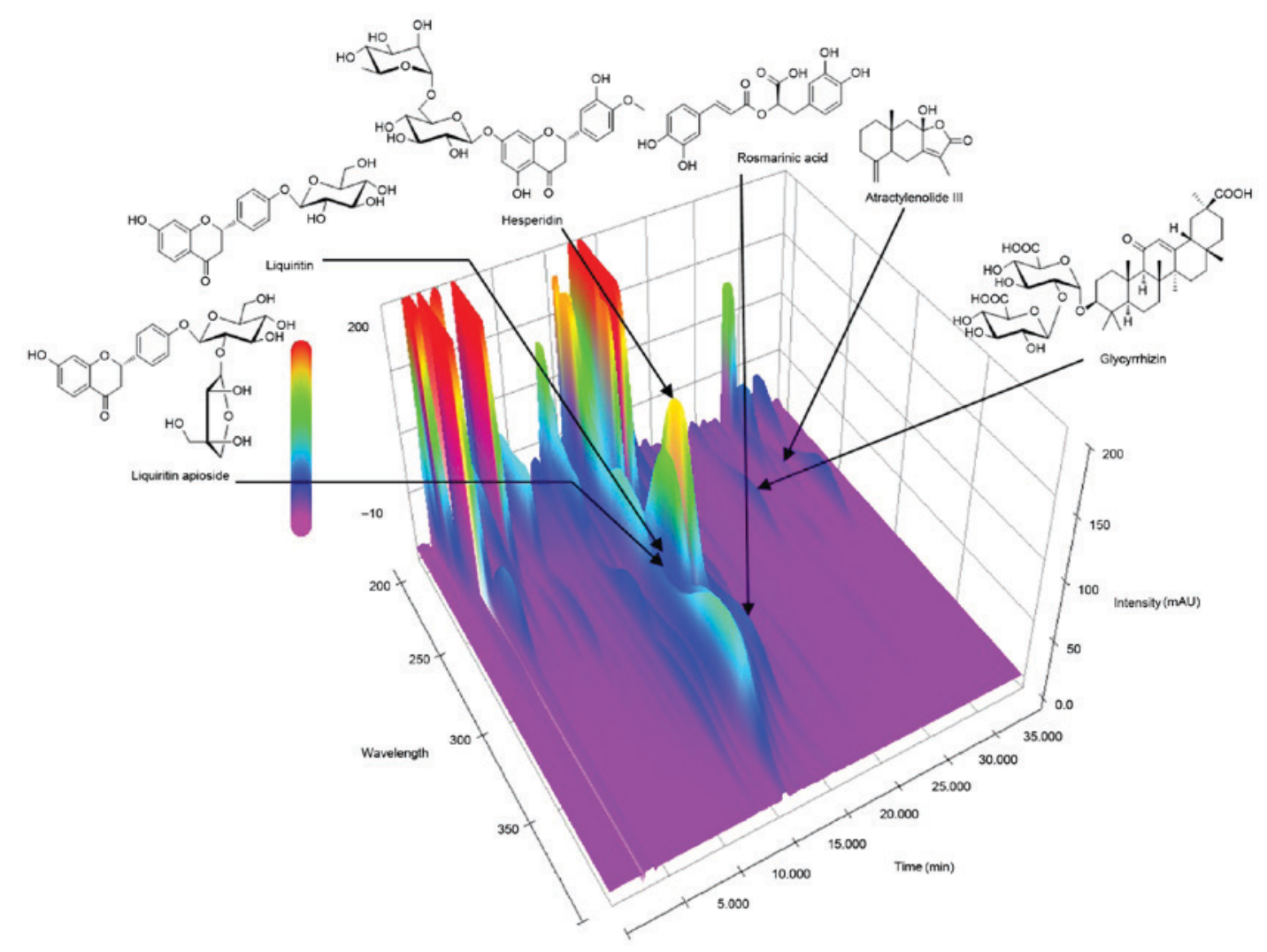

Figure 5. Three-dimensional chromatogram of Hyangso-san sample analyzed by HPLC-photodiode array. HPLC, high-performance liquid chromatography; mAU, milli-absorbance units.

HPLC analysis of the six marker compounds in HSS water extract. The above-described HPLC-PDA method was used for the quantitative analysis of the six marker compounds in the HSS extract. The retention times of liquiritin apioside, liquiritin, hesperidin, rosmarinic acid, glycyrrhizin and atractylenolide III were 16.23, 16.63, 18.33, 19.80, 29.86 and $34.03 \mathrm{~min}$, respectively (Fig. 5). The concentrations of the six marker compounds were calculated using calibration curves of each reference standard; the concentrations of liquiritin apioside, liquiritin, hesperidin, rosmarinic acid, glycyrrhizin and atractylenolide III in the HSS extract were determined to be $1.26,1.82,5.40,1.29,1.70$ and $0.56 \mathrm{mg} / \mathrm{g}$, respectively.

\section{Discussion}

Keratinocytes serve a major role in the regulation of acute and chronic skin inflammation by means of chemokine production (24). Therefore, activated keratinocytes are valuable as an in vitro model for the investigation of inflammatory skin diseases. A number of previous studies have reported that TNF- $\alpha$ and IFN- $\gamma$ stimulation of keratinocytes leads to the generation of specific inflammatory chemokines, including CCL22, CCL17, CCL5 and IL-8 (25-27). To investigate whether HSS has inhibitory effects on skin inflammation, a $\mathrm{HaCaT}$ human keratinocyte cell line was used and stimulated with TNF- $\alpha$ and IFN- $\gamma$ to induce an inflammatory reaction. Consistent with the results of previous studies, the present study demonstrated that TNF- $\alpha$ and IFN- $\gamma$ significantly increased the production and expression of CCL22, CCL17, CCL5 and IL-8 compared with unstimulated cells. Inhibition of CCL17 expression by HSS was not affected by mRNA levels; treatment with HSS extract decreased the expression levels of the chemokines released into the culture supernatants as well as their respective mRNA expression in TNF- $\alpha$ - and IFN- $\gamma$-stimulated HaCaT cells, particularly at a dose of $500 \mu \mathrm{g} / \mathrm{ml}$, which indicated a potential anti-inflammatory effect of HSS extract in the skin.

STAT1 is a member of the STAT protein family and has a crucial role in the IFN/cytokine-signaling pathways (28). The binding of IFN- $\gamma$ to the IFN- $\gamma$ receptor rapidly induces the phosphorylation of Janus tyrosine kinase 1 (JAK1) and JAK2, which subsequently leads to the activation of STAT1 (29). These events ultimately stimulate the production of inflammatory chemokines $(26,27,30)$; therefore, STAT1 is considered as a therapeutic target for the development of anti-inflammatory agents for skin diseases. The results of the present study demonstrated that treatment with HSS extract (at a dose of $500 \mu \mathrm{g} / \mathrm{ml}$ only) suppressed the expression levels of p-STAT1 in TNF- $\alpha$ - and IFN- $\gamma$-stimulated HaCaT cells. Furthermore, HSS treatment reversed the decreased expression of STAT1 that was induced by TNF- $\alpha$ and IFN- $\gamma$ stimulation in $\mathrm{HaCaT}$ cells, which suggested the involvement of STAT1 in the inhibition of inflammatory cytokine production in keratinocytes by HSS.

Notably, the present study conducted a quantitative HPLC-PDA analysis of HSS marker compounds. The principal compounds of the HSS water extract have previously been reported to be the following: The sesquiterpenoid nootkatone from Cyperi Rhizoma (31); the phenylpropanoid rosmarinic acid and the flavonoid luteolin from Perillae Herba $(32,33)$; 
the sesquiterpenoids atractylenolide I and III from Atractylodis Rhizoma (34); the flavonoid hesperidin from Citri Unshii Pericarpium (35); the triterpenoid saponin glycyrrhizin and the flavonoids liquiritin and liquiritigenin from Glycyrrhizae Radix et Rhizoma (36); the phenol 6-gingerol from Zingiberis Rhizoma Crudus (37); the phenylpropanoid ferulic acid and the flavonoid kaempferol from Allii Radix (38). Simultaneous analysis of six compounds (liquiritin apioside, liquiritin, hesperidin, rosmarinic acid, glycyrrhizin and atractylenolide III) in the HSS sample demonstrated that hesperidin was detected as the major compound $(5.40 \mathrm{mg} / \mathrm{g})$.

In conclusion, the results of the present study demonstrated that the Korean traditional herbal formula HSS water extract exhibits anti-inflammatory effects in $\mathrm{HaCaT}$ keratinocyte cells and may function by suppressing chemokine production and expression. In addition, the transcription factor STAT1 may contribute to the HSS-mediated inhibition of the inflammatory response in keratinocytes. Further investigation is required to determine the in vivo activity of HSS using a specific animal model, such as one for atopic dermatitis, and to identify the compound in HSS that may be responsible for the anti-inflammatory action.

\section{Acknowledgements}

This study was supported by a grant from The Korea Institute of Oriental Medicine (grant no. K16251).

\section{References}

1. Dai X, Sayama K, Tohyama M, Shirakata Y, Hanakawa Y, Tokumaru S, Yang L, Hirakawa S and Hashimoto K: Mite allergens is a danger signal for the skin via activation of inflammasome in keratinocytes. J Allergy Clin Immunol 127: 806-814, 2011.

2. Chio JK, Oh HM, Lee S, Kwon TK, Shin TY, Rho MC and Kim SH: Salvia plebeia suppresses atopic dermatitis-like skin lesions. Am J Chin Med 42: 967-985, 2014.

3. Hay RJ, Johns NE, Williams HC, Bolliger IW, Dellavalle RP, Margolis DJ, Marks R, Naldi L, Weinstock MA, Wulf SK, et al: The global burden of skin disease in 2010: An analysis of the prevalence and impact of skin conditions. J Invest Dermatol 134: $1527-1534,2014$.

4. Meagher LJ, Wines NY and Cooper AJ: Atopic dermatitis: Review of immunopathogenesis and advances in immunosuppressive therapy. Australas J Dermatol 43: 247-254, 2002.

5. Werfel T: The role of leukocytes, keratinocytes, and allergen-specific IgE in the development of atopic dermatitis. J Invest Dermatol 129: 1878-1891, 2009.

6. Kakinuma T, Nakamura K, Wakugawa M, Mitsui H, Tada Y, Saeki H, Torii H, Komine M, Asahina A and Tamaki K: Serum macrophage-derived chemokine (MDC) levels are closely related with the disease activity of atopic dermatitis. Clin Exp Immunol 127: 270-273, 2002.

7. Shimada Y, Takehara K and Sato S: Both Th2 and Th1 chemokines (TARC/CCL17, MDC/CCL22, and Mig/CXCL9) are elevated in sera from patients with atopic dermatitis. J Dermatol Sci 34: 201-208, 2004.

8. Oshio T, Sasaki Y, Funakoshi-Tago M, Aizu-Yokota E, Sonoda Y, Matsuoka $\mathrm{H}$ and Kasahara T: Dermatophagoides farinae extract induces severe atopic dermatitis in $\mathrm{NC} / \mathrm{Nga}$ mice, which is effectively suppressed by the administration of tacrolimus ointment. Int Immunopharmacol 9: 403-411, 2009.

9. Casas C, Ribet V, Alvarez-Georges S, Sibaud V, Guerrero D, Schmitt AM and Redoulès D: Modulation of interleukin-8 and staphylococcal flora by Avène hydrotherapy in patients suffering from chronic inflammatory dermatoses. J Eur Acad Dermatol Venereol 25 (Suppl 1): S19-S23, 2011.

10. Tüzün Y, Antonov M, Dolar N and Wolf R: Keratinocyte cytokine and chemokine receptors. Dermatol Clin 25: 467-476, 2007.
11. He C, Medley SC, Hu T, Hinsdale ME, Lupu F, Virmani R and Olson LE: PDGFR $\beta$ signalling regulates local inflammation and synergizes with hypercholesterolaemia to promote atherosclerosis. Nat Commun 6: 7770, 2015.

12. Madonna S, Scarponi C, De Pità O and Albanesi C: Suppressor of cytokine signaling 1 inhibits IFN-gamma inflammatory signaling in human keratinocytes by sustaining ERK1/2 activation. FASEB J 22: 3287-3297, 2008.

13. McAleer MA, Flohr C and Irvine AD: Management of difficult and severe eczema in childhood. BMJ 345: e4770, 2012.

14. Park BK, Park YC, Jung IC, Kim SH, Choi JJ, Do M, Kim SY and Jin M: Gamisasangja-tang suppresses pruritus and atopic skin inflammation in the $\mathrm{NC} / \mathrm{Nga}$ murine model of atopic dermatitis. J Ethnopharmacol 165: 54-60, 2015.

15. Tsai TC, Tung YT, Kuo YH, Liao JW, Tsai HC, Chong KY, Chen HL and Chen CM: Anti-inflammatory effects of Antrodia camphorata, a herbal medicine, in a mouse skin ischemia model. J Ethnopharmacol 159: 113-121, 2015.

16. Jeong SJ, Lim HS, Seo CS, Jin SE, Yoo SR, Lee $N$ and Shin HK: Anti-inflammatory actions of herbal formula Gyejibokryeong-hwan regulated by inhibiting chemokine production and STAT1 activation in HaCaT cells. Biol Pharm Bull 38: 425-434, 2015.

17. Jeong SJ, Lim HS, Seo CS, Kim JH, Jin SE, Yoo SR and Shin HK: Traditional herbal formula Jakyakgamcho-tang (Paeonia lactiflora and Glycyrrhiza uralensis) impairs inflammatory chemokine production by inhibiting activation of STAT1 and NF- $\kappa$ B in HaCaT cells. Phytomedicine 22: 326-332, 2015.

18. Lim HS, Yeji K, Seo CS, Yoo SR, Jin SE, Shin HK and Jeong SJ: Chungsimyeonja-eum inhibits inflammatory responses in RAW 264.7 macrophages and HaCaT keratinocytes. BMC Complement Altern Med 15: 371, 2015.

19. Song BK, Won JH and Kim S: Historical Medical Value of Donguibogam. J Pharmacopuncture 19: 16-20, 2016.

20. Ito N, Nagai T, Yabe T, Nunome $S$, Hanawa $T$ and Yamada $H$ : Antidepressant-like activity of a Kampo (Japanese herbal) medicine, Koso-san (Xiang-Su-San), and its mode of action via the hypothalamic-pituitary-adrenal axis. Phytomedicine 13: 658-667, 2006

21. Hori A, Ito N, Oikawa $\mathrm{T}$ and Hanawa $\mathrm{T}$ : Kososan, but not milnacipran, elicits antidepressant-like effects in a novel psychological stress-induced mouse model of depression. Trad Kampo Med 2: 1-7, 2015.

22. Kang JS, Yoon WK, Han MH, Lee H, Lee CW, Lee KH, Han SB, Lee K, Yang KH, Park SK and Kim HM: Inhibition of atopic dermatitis by topical application of silymarin in NC/Nga mice. Int Immunopharmacol 8: 1475-1480, 2008.

23. Kang NJ, Koo DH, Kang GJ, Han SC, Lee BW, Koh YS, Hyun JW, Lee NH, Ko MH, Kang HK and Yoo ES: Dieckol, a component of Ecklonia cava, suppresses the production of MDC/CCL22 via down-regulating STAT1 pathway in interferon- $\gamma$ stimulated HaCaT human keratinocytes. Biomol Ther (Seoul) 23: 238-244, 2015.

24. Albanesi C: Keratinocytes in allergic skin diseases. Curr Opin Allergy Clin Immunol 10: 452-456, 2010.

25. Ahn S, Siddiqi MH, Aceituno VC, Simu SY, Zhang J, Jimenez Perez ZE, Kim YJ and Yang DC: Ginsenoside Rg5:Rk1 attenuates TNF- $\alpha /$ IFN- $\gamma$-induced production of thymus- and activation-regulated chemokine (TARC/CCL17) and LPS-induced NO production via downregulation of NF- $\mathrm{kB} / \mathrm{p} 38$ MAPK/STAT1 signaling in human keratinocytes and macrophages. In Vitro Cell Dev Biol Anim 52: 287-295, 2016.

26. Lim HS, Jin SE, Kim OS, Shin HK and Jeong SJ: Alantolactone from Saussurea lappa exerts antiinflammatory effects by inhibiting chemokine production and STAT1 phosphorylation in TNF- $\alpha$ and IFN- $\gamma$-induced in HaCaT cells. Phytother Res 29: 1088-1096, 2015

27. Park JH, Kim MS, Jeong GS and Yoon J: Xanthii fructus extract inhibits TNF- $\alpha / \mathrm{IFN}-\gamma$-induced Th2-chemokines production via blockade of NF- $\kappa$ B, STAT1 and p38-MAPK activation in human epidermal keratinocytes. J Ethnopharmacol 171: 85-93, 2015.

28. Takaoka A and Taniguchi T: New aspects of IFN-alpha/beta signalling in immunity, oncogenesis and bone metabolism. Cancer Sci 94: 405-411, 2003.

29. Best SM, Morris KL, Shannon JG, Robertson SJ, Mitzel DN, Park GS, Boer E, Wolfinbarger JB and Bloom ME: Inhibition of interferon-stimulated JAK-STAT signaling by a tick-borne flavivirus and identification of NS5 as an interferon antagonist. J Virol 79: 12828-12839, 2005. 
30. Han EH, Hwang YP, Choi JH, Yang JH, Seo JK, Chung YC and Jeong HG: Psidium guajava extract inhibits thymus and activation-regulated chemokine (TARC/CCL17) production in human keratinocytes by inducing heme oxygenase- 1 and blocking NF- $\kappa$ B and STAT1 activation. Environ Toxicol Pharmacol 32: $136-145,2011$.

31. Seo EJ, Lee DU, Kwak JH, Lee SM, Kim YS and Jung YS: Antiplatelet effects of Cyperus rotundus and its component (+)-nootkatone. J Ethnopharmacol 135: 48-54, 2011.

32. Jeon IH, Kim HS, Kang HJ, Lee HS, Jeong SI, Kim SJ and Jang SI: Anti-inflammatory and antipruritic effects of luteolin from Perilla (P. frutescens L.) leaves. Molecules 19: 6941-6951, 2014.

33. Kim BY, Jeong JS, Kwon HJ, Lee JH and Hong SP: Determination of rosmarinic acid and caffeic acid from Perilla frutescens var. japonica and var. acuta by reversed-phase HPLC. Kor J Herb 23: 67-72, 2008.

34. Jeong SI, Kim SY, Kim SJ, Hwang BS, Kwon TH, Yu KY, Hang SH, Suzuki K and Kim KJ: Antibacterial activity of phytochemicals isolated from Atractylodes japonica against methicillin-resistant Staphylococcus aureus. Molecules 15: 7395-7402, 2010.
35. Liu EH, Zhao P, Duan L, Zheng GD, Guo L, Yang H and Li P: Simultaneous determination of six bioactive flavonoids in Citri Reticulatae Pericarpium by rapid resolution liquid chromatography coupled with triple quadrupole electrospray tandem mass spectrometry. Food Chem 141: 3977-3983, 2013.

36. Zhang Q and Ye M: Chemical analysis of the Chinese herbal medicine Gan-Cao (licorice). J Chromatogr A 1216: 1954-1969, 2009.

37. Lee HR, Lee JH, Park CS, Ra KR, Ha JS, Cha MH, Kim SN Choi Y, Hwang J and Nam JS: Physicochemical properties and antioxidant capacities of different parts of Ginger (Zingiber officinale Roscoe). J Kor Soc Food Sci Nutr 43: 1369-1379, 2014.

38. Parvu M, Toiu A, Vlase L and Alina Parvu E: Determination of some polyphenolic compounds from Allium species by HPLC-UV-MS. Nat Prod Res 24: 1318-1324, 2010 